\title{
What is Islamic economics? The view of Muhammad Baqir al-Sadr
}

\author{
Hafas Furqani \\ Faculty of Islamic Economics and Business, Universitas Islam Negeri Ar-Raniry, Banda Aceh, Indonesia \\ *Corresponding author: hafas.furqani@ar-raniry.ac.id
}

\section{Keywords: \\ Muhammad Baqir al-Sadr, Islamic Economics, Doctrine, Science, Methodology \\ Article History \\ Received : 25 June 2019 \\ Accepted : 9 July 2019 \\ Published: 30 July 2019 \\ DOI: \\ 10.20885/JEKI.vol5.iss2.art3}

\begin{abstract}
Muhammad Baqir al-Sadr (1935-1980) is a well-known Muslim scholar of the late twentieth century. Al-Sadr is considered as one of the pioneers of Islamic revival in the contemporary Muslim world. His keen intellectual interests inspired him to critically study a wide range of areas in contemporary philosophy, economics, politics, sociology, history and law, from a distinct Islamic point of view. Al-Sadr's magnum opus on economics, Iqtisaduna (Our Economics) has put his name as one of the pioneers of contemporary Islamic economics. His work, in various degrees has influenced the formation and development of Islamic economics as a system and as a body of knowledge. This paper attempts to investigate some aspects of al-Sadr's economic thought by focusing on his view on the nature, subject matter and methodology of Islamic economics, areas that have not received sufficient attention by contemporary Islamic economists.
\end{abstract}

JEL:

$\mathrm{B} 12, \mathrm{~B} 32, \mathrm{Z} 12$

\section{Introduction}

Muhammad Baqir al-Sadr (1935-1980) is one of the prominent scholars of Islamic economics. Al-Sadr was born in Kazimia, Iraq, in March 1, 1935. He was an Iraqi Shia cleric, jurist and philosopher and has written a lot of books, such as Iqtisaduna (Our Economics), Bank La Rabbawi Fil Islam (Islamic Banking without Interest), Taudhihul Masail (the book of legal Islamic rulings), Durus fi Ilm al-Usul (Lessons in the Science of Jurisprudence), Falsafatuna (Our Philosophy), Al-Usus al-Mantiqiyyah lil-Istiqra' (Logical Foundations of Induction), Buhuth fi 'Ulum al-Qur'an (Discourses on Qur'anic Sciences), and others.

His magnum opus, Iqtisaduna (Our Economics) which was written in the late 1950's and first published in 1961 put his name as one of the pioneers of contemporary Islamic economics. Many other later scholars were influenced by his comparative approach in explaining the Capitalism, Socialism and Islamic economic system (Wilson, 1998). Although al-Sadr came from a traditional (ulama) background and had no formal training in modern disciplines, his work cannot be underestimated. His keen intellectual interests inspired him to critically study a wide range of areas of contemporary philosophy, economics, politics, sociology, history and law (Mallat, 1994). Reading on his writings, we can say that al-Sadr is original thinker and independent of the dominant Western intellectual paradigm. Al-Sadr's independence of thought is seen as one of the reasons that attracted many scholars to study and explore his works.

Al-Sadr's main writing on Islamic economics, Iqtisaduna, has been praised as an initial comprehensive study that provided an excellent Islamic response to the Western ideologies, Capitalism and Marxism as economic doctrines while at the same time, laying the foundations for an Islamic economic doctrine. It suffices to say that beside al-Sadr's work, so far there is no such comprehensive work on comparative economic system in Islamic perspective.

In the field of economics, apart from Iqtisaduna, (1961), Sadr also penned al-Bank al-la Ribawi fi alIslam (1969). He tried to provide explanations in both works that Islam had its own economic foundations that could be considered as a third economic system apart from Capitalism and Marxism.

Research and writings on al-Sadr's contribution on economic thought are basically exploring those two books. The writings can be classified into two categories: (1) writings that are focusing on exploring Sadr's view on Islamic economics concepts, and (2) al-Sadr's economic view is studied together with the study of Islamic economics in general and/or Iranian economy in particular especially in the formative period after the Islamic revolution of 1979.

Among the scholars who have written al-Sadr's economic thought are Homa Katouzian (1983), T. M. Aziz (1992), Mohamed Aslam Haneef (1995) and Rodney Wilson (1998). Their studies have discussed wide range of al-Sadr's economics ideas ranging from the nature of Islamic economics, his critique of Capitalism and Marxism, the concept of property ownership, production, consumption, distribution, to Islamic banking and finance. In this paper we will exclusively explore Sadr's notion on the nature and methodology of Islamic 
economics. The paper will proceed into four sections that discuss the nature, definition and methodology of Islamic economics according to Baqir al-Sadr respectively, while the final section concludes.

\section{Research Method}

This paper is a qualitative research with a discursive analysis in nature exploring the thought of Muhammad Baqir al-Sadr on the nature of Islamic economics. His magnum opus in Islamic economics, Iqtisaduna is the main focus of this paper with additional perspective from al-Sadr's work on philosophy and religious studies.

To understand al-Sadr's perspective on what Islamic economics, the theme is classified into two dimensions, (1) the nature of Islamic economics by exploring the definition of Islamic economics proposed by al-Sadr and (2) methodology of Islamic economics, i.e., al-Sadr's approach in developing Islamic economics.

\section{Result and Discussion on al-Sadr's View of Islamic Economics}

\section{The Nature of Islamic Economics}

Islamic economics is a new system of thought in the contemporary Islamic intellectual tradition. Scholars, however, have different perspective on the nature of Islamic economics. Is Islamic economics a doctrine or a science? Islamic economics is a 'doctrine' in the sense that it rests on irrefutable principles and aims at changing the realities in accordance with its principles and objectives. On the other hand, Islamic economics a 'science' which is practical in focus and uses rational methods to explain and advise on economic phenomena in the world.

The differences emerge because Islamic economics is unique. Unlike capitalism or socialism, Islamic economics is strongly based on religious teachings and explicitly acknowledges the inclusion of religious principles in the process of theories appraisal and policies prescription. This religious perspective in economics contains doctrine and principles that needs to be operationalized in practice to be evaluated in a scientific perspective, thus Islamic economics could be considered as a scientific discipline.

Nienhaus (2000) argues that Islamic economics should be treated as a science (and not as doctrine) that is developed by serious scientific investigations, using all the well-known scientific methods in economics. As a science, Islamic economics has to be ready for dynamics change as a result of constructive dialogue which cannot be conducted with 'dogmatists' who consider Islamic economics as only a doctrine. If Islamic economics is treated as a doctrine, it will not be able to develop progressively since it is based on these immutable principles explored by a traditional body of knowledge which is no longer sufficient to fully understand contemporary developments and changes.

Nienhaus (1988) therefore argues only positive economics can advance our knowledge about the real world (in the past, present and future) and provide us with the necessary knowledge for a full understanding and assessment of issues in normative economics. Furthermore, as a science, Islamic economics should be a selfquestioning and self-correcting ideological system where disputes are settled only by the persuasive power of arguments. Therefore, Islamic economics must develop techniques to deal with disagreements and differences of opinion by means of intellectual examination.

Al-Sadr (1983), however, has different view on the nature of Islamic economics. Al-Sadr firmly considers Islamic economics (al-iqtisad al-Islami) as a madhhab (doctrine, system, school of thought) ${ }^{1}$ and not as an 'ilm (science). Islamic economics is a doctrine with set of principles derived from the legitimate sources of Islam, i.e. the Qur'an and Sunnah, for human economic life. According to al-Sadr, Islamic economics is a doctrine which is more concerned about discovering every basic rule of economic life connected with the ideology of (social justice)" rather than a science of an "interpretation of existing reality which gives the explanation of economic life, its economic events and its economic phenomena and the linking of those events and phenomena with the general causes and factors which rule therein".

Islamic economics, according to al-Sadr, is like Capitalism and Marxism. They are doctrines that have the role to lay down policies for the organization of economic life based on certain conceptions that are unique to the system. Islamic economics is not a science of economics for science has no role in laying down the policies. Science is interested in studying the effects of a policy which has already been implemented in society. In

\footnotetext{
${ }^{1}$ The word Madhhab has been translated differently by writers to mean system, school of thought, and doctrine. The three meanings are used interchangeably to mean madhhab. If we read Iqtisaduna in its Arabic, some time the word madhhab is appropriate to be translated as 'system' as Sadr attempts to compare and contrast the Islamic economic system with Capitalist and Marxist economic system. Some times the word is appropriate to mean 'school of thought' as Sadr tried to prove that Islamic economics is the third economic school of thought, and some times the word is used to mean 'doctrine' as Sadr's approach to Islamic economics is to derive the 'principles' from the Qur'an and Sunnah to be the foundation of an Islamic economy. The present writer found that the last meaning (doctrine) is more appropriate and mostly used by scholars who translate works on Sadr's.
} 
addition, the science of economics aims at discovering and explaining the phenomena of economic life and their inter-relationship, whereas the objective of a doctrine of economics is to formulate 'laws' based on social justice to be implemented in organizing the economic life of mankind. In other words, the science says what it actually is while doctrine says what it should be (al-Sadr, 1991).

To give a clear understanding, al-Sadr then gives an example. Capitalism is a doctrine (system) that organizes economic life based on a free market economy and arranges the market in a way that sellers are free to fix the prices of their commodities. The science of economics on the other hand does not lay down any new principle for the market. Its job is only to study market trends, price fluctuations and their limitations in a free market organized under the capitalistic system. The question then is why Sadr defines Islamic economics as a doctrine and not as a science? And why Sadr differentiates the two while Islamic economics according to some writers can be a doctrine as well as a science?

There are some possible explanations for this. Fist, al-Sadr, according to Rahnema \& Nomani (1990) was a politico-religious activist cum ideologue of a revolution based in Najaf, Iraq. His role is to provide an ideological explanation of a working Islamic system. He conceived Islamic economics to be a doctrine (ideology) that would change the corrupt 'facts', at least in economic matters, by following Islamic guidelines. False realities (due to alien Western economic system) should be changed to be in consonant with Islamic doctrine, and not vice versa. The compromise and adjustment should be done in one direction. The doctrinal function of the Islamic economy will reveal the full vision of economic life in accordance with the Islamic Shari'ah and will study the ideas and general understanding which radiate from that vision. It cannot be done properly if Islamic economics is a science, for science has no revolutionary power as science is more interested in describing, interpreting and analyzing the existing reality of the economic phenomena. Therefore, Rahnema and Nomani (1990) then see al-Sadr's position on the nature of Islamic economics as a radical interpretation of Islamic economics, which in some cases is not in line with the mainstream view of Islamic economists.

As a doctrine, Islamic economics is an ideological revolution for changing the corrupt (fasid) reality, and turning it into a pure (salim) one. Islamic economics should be posed as an ideology, a universal vision, which would establish a completely different framework for economic activity and social relations (Katouzian, 1983). Al-Sadr in this regard attempts to infuse his ideological revolutionary vision into Islamic economics. He believes Islamic economics as a doctrine has a functional duty to solve the problem of economic life linked with its conceptions of ideology and its ideal of justice. However, if we treat Islamic economics as a science, it would not perform such a role since science is only concerned with understanding the facts as they are and describing cause effect linkage and relationship of those facts. In addition, according to al-Sadr, those realities might be fasid (false) since no Islamic economic system has been established and hence would science of Islamic economics would justify those corrupt facts (false realities). ${ }^{2}$

Second, al-Sadr's interest to consider Islamic economics as a doctrine is due to his view that Capitalism as well as Marxism is more a doctrine than science. Al-Sadr firmly believes that capitalist and Marxist economics are based on certain doctrines. In Iqtisaduna, al-Sadr explores those doctrines of capitalism and Marxism clearly and demonstrates the incompatibility of both Marxism and Capitalism with Islam. He attempts to prove that Islam has a doctrine that is quite different from the doctrine of Capitalism and Marxism and therefore it should be regarded as a third economic system along with them. Therefore, we have seen the comparison of the doctrinal foundation of Capitalism, Marxism and Islam in most parts of Iqtisaduna.

Al-Sadr's view is at least shared by Schumpeter (1954) and Heilbroner (1988) who view modern economics as being preceded by what is called a vision or an ideology. In the case of Capitalism, Spengler (1980) also argues that it is essentially "a product of European civilization with some of its origin dating back to the Greco-Roman and medieval worlds". Heilbroner (1999) therefore considers economics as concerned exclusively with the study of capitalism. Economics is not a science of society at large since its purpose is to help us better understand the capitalist setting in which we will most likely have to shape our collective destiny for the foreseeable future.

Doctrines play a role in shaping the interest of scientists who will put them into operation and determine the questions asked, the problems considered important, and the answers deemed acceptable. In the realm of science of economics, those doctrines will guide in establishing the axioms of theory, the choice of relevant facts, the hypothesis proposed to account for such facts, the criteria used to assess the benefits of competing

\footnotetext{
${ }^{2}$ Al-Sadr's position according to Katouzian (1983) is more or less influenced by his Shi'i background. The Shi'i approach to Islamic economics is slightly different to the Sunni approach. Sunni writers tend to assume that contemporary Muslim societies and the past civilizations from which they evolved are Islamic, whereas Shi'i views that -apart from the short period of Muhammad's and Ali's rule- the Islamic state and political economy have no precedent in history. Therefore, some Shi' $i$ scholars, such as Baqir al-Sadr, Bani al-Sadr, Taleqani and Mutahhari attribute the existing reality as the corrupt reality that needs radical change to become Islamic.
} 
theories, the language in which results are to be formulated and so on (Wilber, 2003). Therefore, all economic theories appraised in conventional economics are not free from the capitalist doctrine. Al-Sadr has attempted to explore those Western-secular values in Capitalism or Marxism which he deemed as not in line with Islamic values.

In this regard, Al-Attas (2005) holds a similar view by insisting that 'Islam is not a form of culture, and its system of thought projecting its vision of reality and truth and the system of value derived from it are not merely derived from cultural and philosophical elements aided by science, but one whose original source is Revelation, confirmed by religion, affirmed by intellectual and intuitive principles. Islam ascribes to itself the truth of being a truly revealed religion, perfected from the very beginning, requiring no historical explanation and evaluation in terms of the place it occupied and the role it played within a process of development'.

Third, considering there is no such integral Islamic system exists anywhere in the world, an attempt has to be made first to delineate the doctrine of Islamic economics to be the principles of an Islamic system. This doctrine will contain a set of socio-economic principles concerning production, consumption and distribution that are designed to create a just society and certain individual attitudes and behaviour that are likely to ensure a society of divine unity (Amuzegar, 1993).

Al-Sadr believes only when the Islamic economic system is in place can the science of Islamic economics be established that explains the working of the system (Behdad, 1995). In al-Sadr's view, it is the doctrine that leads and shapes the science of Islamic economics and not vice versa. To al-Sadr (1991) "the science of Islamic economy cannot possibly develop unless the Islamic economy is realised in its entirety in society, with all its roots, signposts and details, and its economic events and experiments are studied systematically." Therefore, to him it is irrelevant, in this time, to consider Islamic economics as a science while the doctrine of Islamic economics has not clearly been spelled out and well established yet.

In addition, to develop Islamic economics science at the present stage, according to al-Sadr, will be meaningless since no Islamic economic society or Islamic economic system has yet fully developed and the history of Islam provides few precedents on which Muslim scholars can test their hypotheses and base their theories. Therefore, the study of economics as a science in its empirical sense at this stage is irrelevant to the issue of social justice for scientific knowledge rests merely on observation of the (corrupt) reality whose manifestation do not rest on the ideology of justice. The stuy might lead to false conclusion by deriving an Islamic economic theory in the absence of an Islamic economy. The empirical study of economics therefore comes much later to evaluate whether the application of the ideological theory in the realm of life has an adequate basis in reality (Aziz, 1992).

For al-Sadr (1979) there are two pre-conditions have to be established before a science of Islamic economics emerges: (1) Islamic economy as a system has found expression in the society, ${ }^{3}$ and (2) until a methodical examination of past economic experience has been carried out. ${ }^{4}$

Al-Sadr, however, did not elaborate further the second condition since he is not really concerned with the working or scientific bases of Islamic economics. However he elaborated the first condition of how to establish an Islamic economic system. Therefore, although al-Sadr never sought to develop a science of Islamic economics, he never denied the possibility of Islamic economics to be a science when those doctrines are clear. This is evident in his attempt to build a full Islamic system of thought from where a science of Islamic economic could be established in future. However of course, for al-Sadr, the role of Islamic economics as a science should be more than understanding and explaining the realities. It must play a role in taking the economic doctrine of Islam as a set of established principles of society and try to explain them and link events therein with one another. Islamic economics as science will always embody the ideology of justice as its doctrine. ${ }^{5}$ In other word

\footnotetext{
${ }^{3}$ Al-Sadr (1991: 37) argues that "the science of Islamic economics cannot possibly develop unless the Islamic economy is realized in its entirety in society, with all its roots, signposts and details, and its economic events and experiment are studied systematically".

${ }^{4}$ For al-Sadr, as far as modern economies are concerned, traditional Islam has in the word of al-Sadr left in an area of vacuum (mintaqat faragh) for the legitimate authorities to contend with, through a process of ijtihad (original thinking) and ikhtiyar (discretion) (al-Sadr, 1979, 478, 400-404, 416). Therefore to test theories on the basis of social experience at the present stage is not possible for Muslim economists as long as the Islamic economy does not exist.

${ }^{5}$ Perhaps such an outlook is not a monopoly of al-Sadr. Abu al-A'la al-Maududi, a scholar who wrote The Economic Problem of Man and Its Islamic Solution (Lahore, 1941) as observed by Vali Nasr (1994: 109) also has no concern in developing a science of Islamic economics. Maududi viewed Islamic economics as primarily the implementation of Islamic principles in economic life. In his work, he avoided to discuss the technical features of a science of Islamic economics but rather elaborated the principles and explained how they become economic policies of an Islamic state. Both Sadr and Maududi lived in a situation where the Islamic world was experiencing an Islamic resurgence. This situation has pretty much influenced their notion of Islamic economics.
} 
it is a goal-directed activitiy. The role of Islamic economists then is to direct the economic agent (individual and society) as well as science of Islamic economics, to the 'what ought to' in Islamic economic doctrine.

Al-Sadr's strong view to consider Islamic economics as doctrine rather than a science is supported by Alatas (2006). He observed that Islamic economics would be more succesful to be an alternative economics if we considered it as an ethical theory (doctrine) rather than an empirical theory (science). As an empirical theory (science), Islamic economic theory has not done much. It remains within the fold of Western modernist discourse in terms of theoretical concerns and methodology. ${ }^{6}$ However, as an ethical theory (doctrine), Islamic economics offer alternative princples to modernization and dependency on the dominant paradigm.

Al-Sadr's view to have a clear doctrine to be the foundation of Islamic economics prior to develop a science of Islamic economics is further supported by the writings of other critics of Islamic economics who see it as being a replication of conventional economics to the case of Muslim society. Such replication is said to occur because Islamic economics does not have clear and solid philosophical foundations that are projected from an Islamic worldview or vision that truly represents an Islamic approach. Furthermore, this has been the worry of al-Sadr, if we insist to have a science of Islamic economics at this stage with unclear doctrinal foundations, then we will justify the current (corrupt) realities and at worst we will lead those realities into the construction of the doctrine in Islamic economics. By this, of course Islamic ideals of socio-justice would not take root in Islamic economics.

M.A Mannan (1983) does not fully agree with al-Sadr. He does not deny that Islamic economic theory, being a science, draws its principles from the Islamic economic doctrine. However he does not agree that due to the absence of an actual Islamic economy, science (theory) of Islamic economics becomes unnecessary as argued by al-Sadr. If we hold that view, he says, we follow the positivists view who consider the presence of data as primary conditions for developing economic theory. Positivist might say there is no need to develop Islamic economic theory because an actual Islamic economy where ideas could be tested against actual problems is absent. Since we have no real evidence of economic phenomena, then Islamic economic theory is irrelevant as it has nothing to understand and explain from the existing socio-economic reality of contemporary Muslim societies.

Mannan (1986) argues that science or economic theory might not be necessarily designed to explain current reality; in fact, it is designed to explain perceived or expected reality. He gives an example. In 1776 Adam Smith wrote The Wealth of Nations, freedom of trade was not the order of the day. However he could foresee the need for it in view of the social and economic transformation which was taking place in Britain. In 1867, the first volume of Das Capital by Karl Marx was published that initiated the modern science of Socialism and Communism. Their works were not originally designed to explain the current reality, however the perceived reality that have paved the way for innovations in economic theory and economic life of subsequent generations.

Furthermore, Mannan (1986) puts three following reasons to develop Islamic economic science and theory: (1) to draw the lessons of past experience by identifying the reasons for adequacy or inadequacy of explaining the past economic behaviour and practices by Islamic economic theory; (2) to explain the actual economy however fragmented it might be; (3) to identify the gap between the ideal Islamic economic theory and actual practices of contemporary Muslim society, thus an attempt can be made to reach an ideal situation.

Mannan (1986) might view that the construction of doctrine and science of Islamic economics could be done in a simultaneous way. It is true that doctrine has to be first, however the analytical part of the science of Islamic economics should not be neglected and postponed. It should be developed right from the beginning because the science grows in a gradual or an evolutionary way. However this should not lead Islamic economists to replicate all models in conventional economics and put the stamp Islamic when they are used to test Muslim societies/countries. The science and theory of Islamic economics in Mannan's view should be genuine where the first step is establishing the fundamental principles governing economic life from the primary resources, Qur'an and Sunnah. These principles have no time dimension and are essentially based on the Islamic worldview in economic matters. Economic theory produced in subsequent steps must follow this primary guideline.

What Mannan (1986) says as perceived reality is a pre-scientific action of a science in the Schumpeterian sense whose source is ideology. It is an extra scientific vision of the economic process. That prescientific cognitive act which is the source of our ideologies is in fact the prerequisite of our scientific work. No new departure in any science is possible without it. And both should be viewed as integrated as said by Schumpeter (1949) "to investigate facts or to develop tools for doing so is one thing: to evaluate them from some

\footnotetext{
${ }^{6}$ Syed Farid Alatas (2006) then continues criticizing Islamic economics as an empirical theory with 'neo-classical guise' that "merely substituted Islamic terms for neo-classical ones, retaining the latter's assumptions, procedures and modes of analysis. As such, it has failed to engage in the analysis and critique of a highly unequal world economic order in which the gaps are ever widening". Perhaps, this could be the reason of why Sadr does not prefer to have a science of Islamic economics before a doctrine of Islamic economics is well established.
} 
moral or cultural standpoint is another thing, and the two need not conflict." Therefore, according to Pluta (1991), Adam Smith, Karl Marx and John Keynes are visionaries, prophets or socio-economic architects rather than scientists, in the sense that they have not relied primarily on the scientific method, however they have invoked the reign of intellectual authority of intellectual authorities of their times in their socio-economic blueprints to convince their audiences of the validity of their prophetic messages. Iqtisaduna, likewise, is alSadr's blueprint, vision, doctrine of Islamic economics. The difference is in discovering and establishing the doctrine, Sadr mainly relied on the original sources of Islamic legitimate knowledge, the Qur'an and Sunnah.

Scientific process, therefore, is designed to assess, describe and explain economic realities based on those visions or doctrines. These scientific works later will assess the gap that could exist between ideals and economic realities. By this reason, we could understand why al-Sadr would like to put more emphasis on doctrinal discovery and establishment rather than scientific mechanism as scientific process is the logical consequence once we have a clear vision of what to analyse (Furqani \& Haneef, 2012 and Furqani, 2015b).

\section{Definition of Islamic Economics}

Based on his concept of Islamic economics as a doctrine and not as a science, al-Sadr then defines Islamic economics as "the way Islam prefers to follow in the pursuit of its economic life and in the solution of its practical economic problems in line with its concept of justice". Islamic economics according to al-Sadr is a set of doctrine for the organization of economic life based on Islamic principles. It provides guidance for the working economy in real life in all economic activities of allocation of resources, exchange, consumption, production and distribution.

Al-Sadr is not the scholars defining Islamic economics as a system or doctrine. Some scholars have shared similar definitions. Muhammad Abdullah al-Arabi (1969) defines Islamic economics as a set of principles derived from the Qur'an and Sunnah and construct the economics based on those principles according to times and places. ${ }^{7}$ Hasanuzzaman (1985) defines Islamic economics as the knowledge and application of injunctions and rules of the sharicah (Divine Islamic law) that prevent injustice in the acquisition and disposal of material resources in order to provide satisfaction of human beings and enable them to perform their obligations to Allah and the society. Hasan (1996) considers Islamic economics as that aspect of Islam's social doctrine which deals with problems of choice in the face of uncertainty and resource scarcity to promote falāh in a holistic framework.

Here, scholars define Islamic economics as a doctrine that contains a set of principles derived from the Qur'an and Sunnah to be applied in the realm of economics instead of a science that studies economic problems and the behaviour of economic agents in allocating resources based on the values, doctrines, principles and institutions derived from Islamic principles. For al-Sadr, the subject matter of Islamic economics is not in analysing the behaviour of economic agents or in allocation of resources. However in building the doctrine, principles of economics in the realm of economic activities (i.e., property ownership, consumption, production, distribution, etc) based on the source of knowledge in Islam, i.e. the Qur'an and Sunnah (Furqani, 2018).

\section{Methodology of Islamic Economics}

Following his conception of the nature of Islamic economics which considers Islamic economics as a doctrine rather than a science, his methodology of Islamic economics does not follow the common scientific method of conventional economics. Such a position is not because al-Sadr is unaware of the scientific method as commonly misunderstood by some writers. Al-Sadr properly understand the role of a science as well as the scientific method to produce a theory that will describe and explain the causal relationship economic phenomena, as he puts that "science of economics is an interpretation of existing reality which gives the explanation of economic life, its economic events and its economic phenomena and the linking of those events and phenomena with the general causes and factors which rule therein." 8

However, he does not prefer the scientific method to be the methodology of Islamic economics since such an approach to Islamic economics is not appropriate and inadequate to the nature of Islamic economics which is a "doctrine" that seeks to construct the general principles and rules of Islam regarding human economic life based on the primary source of knowledge in Islam, the Qur'an and Sunnah. The common scientific method is not adequate since it merely deals with deriving and establishing economic theories based on the observation of the facts, without dealing with divine revelation.

Islamic economics, on the other hand, puts primary emphasis initially on the principles found in the Qur'an and Sunnah. Islamic economics as a doctrine is interested in outlining and establishing the principles and

\footnotetext{
${ }^{7}$ Quoted from Kamāl Tawfīq Muhammad Al-Hațțāb (2003: 3).

${ }^{8}$ See also his Falsafatuna that discusses the weaknesses conventional scientific methods in producing proper knowledge.
} 
rules (al-mabadi' wa al-usul al- 'ammah li majal al-iqtisad) from where the theories and policies of Islamic economics can be deduced. These principles are derived directly from the original sources of Islam namely the Qur'an and Sunnah rather than from the facts (realities) as in conventional economics. These principles are characterized by 'umum (universal), kulliyyah (general), tsubut (permanent), al-taujihat al-asasiyyah (the principles of guidance) and al-hajat al-asasiyyah al-lazimah (related to only the common needs principle) for every individual and society. These principles are not many in term of quantity but they cover up all the things of human economic matters and are suitable for all time and place (Al-Qaradawy,1995 and Furqani \& Haneef, 2012).

Al-Sadr defines those principles/doctrine as an upper structure to be the base and foundation where numerous particular policies and theories can be derived to be applied in the real economic life based on particular time and place. This particular dimension of theories is not-permanent and open for changes (taghayyur) based on the maslaha according to time and place. The way to construct the principles is more like the fuqaha (jurists) who construct al-qawa'id al-fiqhiyyah (legal maxims) to be applied in particular. They can be taken from the texts directly or indirectly. The direct approach is by deriving the principle right from the text, such as the principle of justice or no exploitation (la tazlimuna wa la tuzlamuna). The indirect approach is based on the upper level of the Islamic edifice and on guidance from the laws by which Islam regulate the matters. This is because there are some fundamental theories and ideas that are not easy to reach by direct texts..

$\mathrm{Al}-\mathrm{Sadr}$ defines that process is a process of discovery whereby all economic laws and injunctions, together with numerous concepts related to economics and society (such as vicegerency, justice, property, ibadah, etc.) are studied together and then used to 'discover' the economic doctrine. Sadr's approach in this regard is a deductive approach (istinbat) that attempts to deduce the principles of economics from the Qur'an and Sunnah by which Muslim should manage their economic affairs.

Interestingly, although al-Sadr considers Islamic economics as a doctrine and his approach to some writers is a juristic approach in economics (Wilson, 1998 and Mallat, 1994), he rejects the idea that Islamic economics is fiqh al-mu'amalah. Although Islamic economics in his conception is a doctrine upon which laws relating to economics are shaped, it is not equivalent to figh al-mu'amalah for the latter has different scope and framework of study. Al-Sadr firmly clarifies that fiqh al-mu'amalah speaks of a collection of laws of Islam by which it regulates property rights (huquq al-maliyyah) and business transaction and rules of dealing (almu'amalah) such as sale, lease (hire), partnership, adulteration, gambling, deceit and so on. Islamic economics' scope of study is wider than merely on legal basis of economic life as it relates to consumption, production and distribution.

In producing theories of Islamic economics, al-Sadr also sees the importance of ijtihad (independent intellectual assertion) to fill the gap between permanent principles and flexible laws, to determine the limits of enquiry and to organize, theoretically, the laws and concepts into a coherent whole. However in the ijtihad process, a qualified intellectual assertion is required to accomplish those tasks.

To fulfil thae requirement, al-Sadr warns of the problem of subjectivity in ijtihad which could lead to disagreement in opinions. He lists four factors that could lead the mujtahid into subjective interpretation:

(a) justification (intentionally or unintentionally) of the existing (defective, fasid) reality in which he is living.

(b) incorporation of the text in a definite framework (non-Islamic framework).

(c) separation of legal (shari'ah) evidence (ground) from its conditions and circumstances in an operation of the extension of the legal ground without objective justification.

(d) adoption of a pre-determined point of view towards the texts.

However, al-Sadr is fully aware that differences of opinion must be there in any ijtihadi process. However al-Sadr maintains that these differences of opinion must be within the bounds of allowable disagreement. Within these bounds, according to Haneef (1995), al-Sadr allows the possibility of varying opinions on economic matters which are legally sound and derived from the Qur'an, Sunnah and saying of the imams. In fact, al-Sadr prefers this flexibility, rather than dogmatic adherence to the opinion of one mujtahid. Therefore, Islamic economics as a doctrine as conceived by al-Sadr in his Iqtisaduna, should not be understood as a rigid dogma as claimed by Nienhaus (2000) but rather to provide the foundations as the working basis for the system of Islamic economics in general, and potentially for the science of Islamic economics to operate.

\section{Conclusion}

Muhammad Baqir al-Sadr is among the earlier contributors of Islamic economics. His keen interest was in exploring and discovering the doctrine and principles of Islamic economics based on the primary sources of Islam. His initial works has influenced subsequent Islamic economists in the development of Islamic economics. 
Al-Sadr's work, Iqtisaduna, is still recognized as a magnum opus in Islamic economics literature and considered as a pre-requisite reading in Islamic economic studies. His understanding on the nature, subject matter and methodology of Islamic economics basically reflects his intellectual and activist background. Al-Sadr's conception of Islamic economics is often categorized as a radical approach in Islamic economics, in contrast to the mainstream approach in Islamic economics. Al-Sadr's contribution is mainly in developing the doctrine of Islamic economics to be the foundation of Islamic economic system. He strongly believed that no science of Islamic economics could be established in the absence of a doctrine of Islamic economics. His keen effort was in establishing these doctrines prior to any analytical study. His methodology therefore followed his concept of the nature of Islamic economics and was directed on how to discover and establish the doctrine of Islamic economics from the primary sources of Qur'an and Sunnah.

\section{References}

Al-Sadr, M. B. (1961, repr. 1968). Iqtisaduna. Beirut.

Al-Sadr, M. B. (1983). Iqtisaduna: Our Economics. Tehran, Iran: World Organization for Islamic Services.

Al-Sadr, M. B. (1991). The Islamic School of Economics. In Muhammad Baqir al-Sadr and Ayatullah Sayyid Mahmud Taleghani (eds.), Islamic Economics: Contemporary Ulama Perspective, (pp. 20-30), Kuala Lumpur: Iqra.

Al-Sadr, M. B. (1991). General Edifice of the Islamic Economy. In Muhammad Baqir al-Sadr and Ayatullah Sayyid Mahmud Taleghani (eds.), Islamic Economics: Contemporary Ulama Perspective, (pp. 31-47), Kuala Lumpur: Iqra.

Aziz, T. M. (1992). An Islamic perspective of political economy: The view of Martyr Muhammad Baqir al-Sadr. Al-Tawhid, 10 (1).

Haneef, M. A. M. (1995). Contemporary Islamic Economic Thought: A Selected Comparative Analysis. Kuala Lumpr: Ikraq

Ahmad, K. (1992). Nature and significance of Islamic Economics. In Ausaf Ahmad and Kazim Raza Awan (eds.), Lectures on Islamic economics (pp. 19-31). Jeddah: IRTI - IDB.

Alatas, S. F. (2006). Islam and the Science of Economics. In Ibrahim M. Abu Rabi' (ed.), The Blackwell Companion to Contemporary Islamic Thought. USA: Blackwell Publishing.

Al-Attas, S. M. N. (2005). Islamic philosophy: An introduction. Journal of Islamic Philosophy, 1(1), 11-43

Al-Hattab, K. T. M. (2003). Manhajiah al-bahts fi al-iqtisad al-Islami wa 'alaqutuhu bi al-nusus al-shari'ah. JKAU: Islamic Economics, 16 (2), 3-40.

Al-Qaradawy, Yusuf. (1995). Daur al-Qiyam wa al-Akhlaq fi al-Iqtisad al-Islamy. Al-Qaherah: Maktabah Wahbah.

Amuzegar, Jahangir. (1993). Iran's Economy under the Islamic Republic. London: I.B. Tauris.

Arif, M. (1985). Towards a definition of Islamic economics: Some scientific consideration. Journal of Research in Islamic Economics, 2 (2), 87-103.

Behdad, S. (1995). Islamization of economics in Iranian universities. International Journal of Middle East Studies, 27, 193-217.

Chapra, M. Umer. (1996). What is Islamic economics. Jeddah: IRTI - IDB.

Choudhury, Masudul Alam. (1986). Contributions to Islamic economic theory: A study in social economics. New York: St. Martin's Press.

Furqani, H \& Haneef, M. A. (2012). Theory appraisal in Islamic economic methodology: Purposes and criteria. Humanomics, Journal of System and Ethics, 28 (4), 270-284.

Furqani, H. (2015a). Individual and society in an Islamic ethical framework: Exploring key terminologies and the micro-foundations of Islamic economics. Humanomics, Journal of System and Ethics, 31(1), 74-87.

Furqani, H. (2015b). The discipline in the making: Appraising the progress of Islamic economics. Journal of Islamic Monetary Economics and Finance, 1 (1), 1-23. 
Furqani, H. (2018). Defining Islamic economics: Scholars' approach, clarifying the nature, scope and subjectmatter of the discipline. Turkish Journal of Islamic Economics, 5(2), 69-93.

Hasanuzzaman, S.M. (1985). Definition of Islamic economics. Journal of Research in Islamic Economics, 2 (2), 51-53.

Hasan, Z. (1996). Review of Akram Khan's an introduction to Islamic economics. American Journal of Islamic Social Sciences, 13 (4), 580-585.

Heilbroner, R. (1988). Behind the Veil of Economics. Ontario: W.W. Norton and Company.

Heilbroner, R. (1999). The Worldly Philosophers. ( $7^{\text {th }}$ revised edition). New York: Simon and Schuster.

Kahf, M. (2003). Islamic economics: Notes on definition and methodology. Review of Islamic Economics, 13, 23-47.

Khan, M. A. (1984). Islamic economics: Nature and need. Journal of Research in Islamic Economics, 1 (2), 5561.

Katouzian, H. (1983). Shi'ism and Islamic Economics: Sadr and Bani Sadr. In Nikki R. Keddie (Ed.), Religion and Politica in Iran: Shi'ism from Question to Revolution, (pp. 145-165). New Heaven and London: Yale University.

Mannan, M. A. (1986). Islamic Economics: Theory and Practices. Cambridge: Hodder and Stoughton.

Mannan, M. A. (1983). Islamic economics as a social science: some methodological issues. Journal of Research in Islamic Economics, 1 (1), 41-50.

Mallat, C. (2005 [994]). Muhammad Baqer as-Sadr. In Ali Rahnema (ed.), Pioneers of Islamic Revival, (pp.251272), London: Zed Books Ltd.

Nasr, S. V. R. (1994). Mawdudi and the Jama'at -i Islami: The origins, theory and practice of Islamic reivalism. In Ali Rahnema (ed.), Pioneers of Islamic Revival, (pp. 98-124), London: Zed Books Ltd.

Naqvi, S. N. H. (1994). Islam, economics and society. London: Kegan Paul International.

Nienhaus, V. (2000). Islamic economics: Dogma or science. In Kay hafez (ed.), The Islamic world and the West, (Mary Ann Kenny, trans.) (pp. 86 - 99). Leiden: Brill.

Nienhaus, V. (1988). Restaments of normative economcis: Western approach and Islamic perspectives. In Masudul Alam Choudhury (ed.), Policy-theoretic Foundations of Ethico-Economics. Cape Bretton: The centre of Humanomics, Univsrsity Colege of Cape Bretton.

Pluta, L. (1991). Predictions, prophecies and economics: The ontological foundation of the discipline of economics. Humanomics, 7 (1), 19-48.

Rahnema, A. (1994). Pioneers of Islamic Revival. London: Zed Books Ltd.

Rahnema, A \& Nomani, F. (1990). The Secular Miracle: Religion, Politics and Economic Policy in Iran. London: Zed Books.

Schumpeter, J.A. (1994). Science and ideology. In Daniel M. Hausman (ed.), The Philosophy of Economics: An Anthology, (pp. 224-238), Cambridge: Cambridge University Press.

Schumpeter, J.A. (1954). History of economic analysis. London: George Allen and Unwin.

Spengler, J. J. (1980). Origin of Economic Thought and Justice. USA: Southern Illinois University Press.

Wilber, C. K. (2003). Ethics and economic theory. Post-Autistic Economics Review, 20, article 1. Retrieve form http://www.paecon.net/PAEReview/issue20/Wilber20.htm.

Wilson, R. (1998). The contribution of Muhammad Baqir al-Sadr to contemporary Islamic economic thought. Journal of Islamic Studies, 9 (1), 46-59. 